\title{
Boycotting South Africa
}

SIR - In response to J.G. Wilson (Nature 328, 288; 1987), we should like to present our case against a total academic boycott of our scientists.

We have no doubts that trade and sports boycotts against South Africa have been effective; any government moves towards reform can be attributed to such pressures. That is why academics elsewhere are seeking to produce similar effects by boycotting our universities, as in disallowing South African participation in international conferences, a reluctance to attend conferences in this country and the rejection of South African contributions by international journals.

It is interesting that, largely as a result of these measures, many South African academics have become so conscious and so defensive - of academic freedom. These same people have, however, remained conspicuously silent about the erosion of freedom when the infringements have involved members of the political left. Such infringements occur daily. The more spectacular examples include the prolonged detention of our staff and students, occupation of the campus by heavily armed police, banning of meetings, tear-gassing and assault of staff and students by police and the destruction of property. But far more common, and perhaps more insidious, are the instances of staff being ostracized by colleagues, the withdrawal of work permits by the authorities, the threat of deportation, the opening of university mail and the tapping of telephones.

All is not, therefore, as Wilson sees it. Far from "living comfortably in South Africa", many of our liberal academics are suffering from oppression. To oppose apartheid in Britain is easy and is even encouraged; to oppose it here is dangerous. How would Wilson survive 13 months' detention in prison without trial, as has our colleague Raymond Suttner? The price we pay for opposing the government in this country can be very high indeed. It can be only a matter of time before a student is killed on campus.

Is a total academic boycott likely to advance the struggle against apartheid in any way? We remain unconvinced. Academic isolation will not be immediately destructive, but it will have dire consequences in the long term. Traditions of academic excellence are not built overnight, and, once destroyed, are almost impossible to rebuild. It is clear that the present government will not relinquish power until it is forced by bankruptcy to do so. Our economic recovery thereafter will depend on the continued existence of a sophisticated system of education and training. In stifling the monster of apartheid, we must take care to protect the embryonic nation that is struggling to be born.

If our educational institutions are destroyed now because of the isolation of their academics, no subsequent government will be able to raise the country from its inevitable plunge into under-development and exploitation. By all means, let us continue to fight for the equal allocation of South Africa's resources to all its people, but let us also ensure that there will be something worth sharing, once this government has ceased to exist.

A total boycott of the South African education system is as wrong as no boycott at all. What we suggest is a system to identify opponents of apartheid within South Africa based on a signed declaration that echoes the aspirations of the Freedom Charter:

All the cultural treasures of mankind shall be open to all, by free exchange of books, ideas and contact with other lands;

Education shall be free, compulsory, universal and equal for all children.

Higher education and technical training shall be opened to all by means of state allowances and scholarships awarded on the basis of merit.

Let all South Arican academics who wish to be considered a part of the international community and those overseas academics who wish to visit here and speak on our campus be invited to sign such a declaration. This implies the implementation of selective sanctions against those who support the principles of apartheid. It is only by such action that academic opposition to apartheid both inside and outside this country can be united.

In this way we should, through academic responsibility, ensure that the liberal universities retain their standards of academic excellence, that they remain members of the international community and that they resist intimidation from all who would break down their liberal ideals.

R.J. RAYNER J.C.MASTERS

University of the Witwatersrand,

Witwatersrand 2050 ,

South Africa

SIR-The clear vision, unquestioning faith, absolute judgement and fervent determination that J.G. Wilson (Nature $\mathbf{3 2 8}$, $288 ; 1987)$ brings to bear in his discussion of the academic boycott of South Africa are exactly those attributes that characterize the Nationalist Party and its relentless misgovernment of South Africa.

Neither the nationalists (of whatever 'colour') nor Wilson seem to realize that the present political crisis (as it relates to racism) is destined to be overrun by the real problems of population growth. While the various factions invest their effort in the battle for political supremacy, they appear to be oblivious of the forces that could reduce their inheritance to a wasteland.

The population of South Africa is expected to increase from the present 30 million to 80 million by 2020 . So, for the foreseeable future, the population profile will be dominated by children who do not contribute to the country's work-force but who place an ever-increasing load on agriculture, water supply, health, education and technical services. Already more than half of the population of South Africa is below the age of 20 . South Africa must maintain a real growth rate of 4.5 per cent merely to provide employment opportunities to meet the population growth. This is hardly the time to persuade trained people and entrepreneurs to leave the country, or to ostracize those who remain. Even less is it the time to destroy (as opposed to transform) the economy required to support new lives as well as to provide for a new political dispensation with a generally enhanced standard of living.

Under any other circumstances, there would be little doubt about the solution to a problem of this kind. We would recommend that skills, education and agriculture be nurtured. We would recommend the development of a robust local industry with a significant export market. We would encourage entrepreneurs and investment. Instead, both the Nationalist Party and the international community are blinded by the issues of racism. The Nationalist Party is prepared, if necessary, to spend its last years dragging southern Africa into the abyss of war. The international community, intent on vengeance, is determined to see the downfall of 3 million white Nationalists at the cost of decimating the whole infrastructure of that same subcontinent. Their position is usually justified on the grounds that, hopefully, the devastation need only be transient. Unfortunately, phoenix-like revival of fortunes has not been a characteristic of the post-colonial developing countries. Wilson and his like would do well to be more circumspect before encouraging 30 million people onto a course of self-destruction.

I suggest that the only strategy that could save the southern African region from an irreversible slide into economic and social oblivion is determined and selective foreign investment in black business and education. Racism can be conquered by education and economics, but not by wars.

104 c Banbury Road,

Oxford OX2 6JX, UK

Rodney J. Douglas

Letters submitted for Correspondence should be typed, double-spaced, on one side of the paper only. 